Mar. Drugs 2004, 2, 185-191

Marine Drugs

ISSN 1660-3397

www.mdpi.net/marinedrugs/

\title{
Philinopgenin A, B, and C, Three New Triterpenoid Aglycones from the Sea Cucumber Pentacta quadrangulasis
}

\author{
Shi-Long Zhang, Ling-Li, Yang-Hua Yi *, Zheng-Rong Zou and Peng-Sun
}

Research Center for Marine Drugs, School of Pharmacy, Second Military Medical University, 325 Guo-He Road, Shanghai 200433, P. R. China. Fax: (+86)-21-65483662

*Author to whom correspondence should be addressed; E-mail: yiyanghua@hotmail.com

Received: 17 May 2004 / Accepted:16 October 2004 / Published: 25 November 2004

\begin{abstract}
Three new triterpenoid aglycones named Philinopgenin A (1), B (2), and C (3) were isolated from the acid hydrolysate of the crude glycoside mixture prepared from the whole sea cucumber Pentacta quadrangulasis Lesson. The corresponding

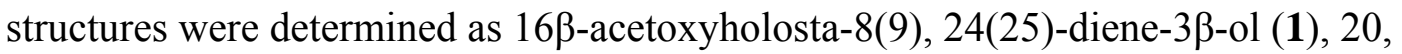

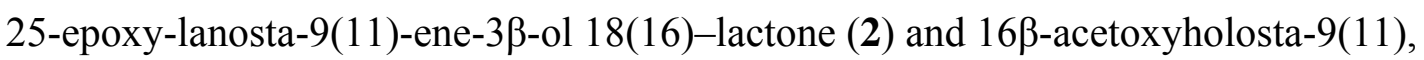
$24(25)$-diene-3 $\beta$-ol (3), respectively, on the basis of spectral evidence.
\end{abstract}

Keywords: Pentacta quadrangulasis Lesson, Philinopgenin A, Philinopgenin B, Philinopgenin $\mathrm{C}$, triterpenoid aglycone.

\section{Introduction}

Investigations of triterpene glycosides in sea cucumbers (Holothuroidea, Echinodermata) have a long history. In the search for new biologically active substances from marine organisms, we have been investigating antitumour constituents in the sea cucumber Pentacta quadrangulasis Lesson, which is widely distributed throughout the South China Sea, especially in the area near Guangdong. Before examining the components of this sea cucumber to elucidate the structure of the biologically active glycosides, we investigated the aglycones. We report herein the isolation, purification, and structural elucidation of three new aglycones named Philinopgenin A (1), B (2), and C (3) from the acid hydrolysate of the crude glycoside fraction. 


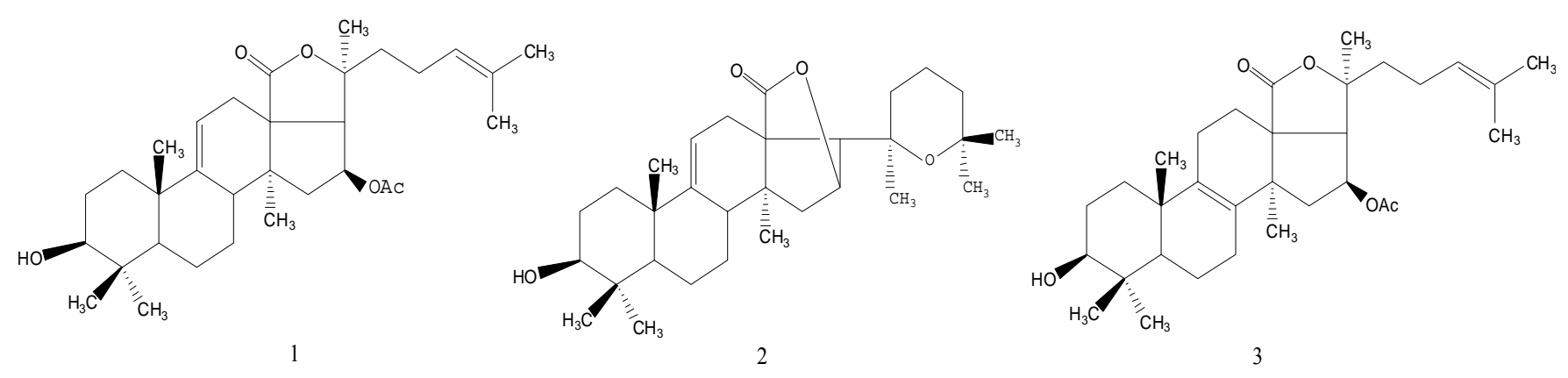

\section{Results and Discussion}

The molecular formula of Philinopgenin A (1) was determined as $\mathrm{C}_{32} \mathrm{H}_{48} \mathrm{O}_{5}(\mathrm{~m} / \mathrm{z} 512)$ by the pseudomolecular ion peaks at $\mathrm{m} / \mathrm{z} 512\left([\mathrm{M}]^{+}\right)$and $535\left([\mathrm{M}+\mathrm{Na}]^{+}\right)$in the HRESI-MS (positive-ion mode). The IR spectrum showed absorptions due to hydroxyl $\left(3443 \mathrm{~cm}^{-1}\right), \gamma$-lactone $\left(1770 \mathrm{~cm}^{-1}\right)$ and carbonyl $\left(1748 \mathrm{~cm}^{-1}\right)$ functions. The structure of compound $\mathbf{1}$ was deduced from extensive NMR spectroscopy studies ( ${ }^{1} \mathrm{H}$ - and ${ }^{13} \mathrm{C}-\mathrm{NMR}$, DQCOSY, HMQC, and HMBC, Table 1). These spectra indicated that compound $\mathbf{1}$ is a triterpenoid compound with two olefinic bonds, one ester, and one lactone carbonyl group. These features showed a close similarity to those reported for the triterpenoid lactone aglycone stichopogenin $\mathrm{A}_{2}$, isolated from the acid hydrolysate of holotoxin $\mathrm{A}$ [1]. The ${ }^{13} \mathrm{C}-\mathrm{NMR}$ and DEPT spectra exhibited 32 carbon signals $\left(8 \times \mathrm{CH}_{3}, 8 \times \mathrm{CH}_{2}, 7 \times \mathrm{CH}, 9 \times \mathrm{C}\right)$. The ${ }^{1} \mathrm{H}$-, ${ }^{13} \mathrm{C}$ - and DEPT spectra of compound 1 showed resonances for a 9(11)-double bond $\left[\delta_{\mathrm{C}}\right.$ $110.8(\mathrm{~s}, \mathrm{C}-11)$ and $151.2(\mathrm{~S}, \mathrm{C}-9)]$ and those due to an acetoxy group $\left[\delta_{\mathrm{C}} 170.0(\mathrm{~s})\right.$ and $21.4(\mathrm{q}) ; \delta_{\mathrm{H}}$ $1.93(3 \mathrm{H}, \mathrm{s})]$. The location of the acetoxy group at $\mathrm{C}-16$ was deduced from the chemical shift of the H-16 signal ( $\delta 5.76)$, which showed coupling to signals at $\delta 2.57$ (H-17 $\alpha), 2.19(\mathrm{H}-15 \alpha)$, and 1.43 (H-15 $\beta$ ) in the DQCOSY spectrum. This conclusion was also confirmed by the cross peak at $\delta$ $5.76 / 170.0\left(\mathrm{H}-16 / \mathrm{CH}_{3} \mathrm{CO}\right)$ in $\mathrm{HMBC}$ spectrum. The $16 \beta$ configuration of the acetoxy group was confirmed by NOESY experiments and by coupling constant analysis for the C-16 proton with the $\mathrm{C}-17 \alpha$ proton (see Figure 1a). The calculated coupling constant value of $9.6 \mathrm{~Hz}\left(\mathrm{~J}_{16 \alpha}, 17 \alpha\right)$ for the most stable conformation of 16 $\beta$-acetoxy-holosta-9,24-diene-3 $\beta$-ol obtained by Molecular Mechanics (Hyperchem) coincided with the experimental and reported values [2] and differed considerably from those calculated for $16 \alpha$-isomer $\left[1.2 \mathrm{~Hz}\left(\mathrm{~J}_{16 \beta}, 17 \alpha\right)\right]$. The ${ }^{1} \mathrm{H}-\mathrm{NMR}$ spectrum showed two vinyl methyl signals at $\delta 1.50$ and 1.57 and one olefinic proton signal at $\delta$ 5.04, assigned to the terminal isopropenyl group of the side chain. The ${ }^{13} \mathrm{C}-\mathrm{NMR}$ spectrum confirmed the presence of this group: two methyl groups at $\delta 25.5$ (C-26) and $17.7(\mathrm{C}-27)$ attached to olefinic carbons at $\delta 131.8(\mathrm{C}-25)$ and $124.4(\mathrm{C}-24)$. This conclusion was also confirmed in the HMBC spectrum. Therefore the structure of compound 1 was determined as 16 $\beta$-acetoxyholosta-9(11), 24(25)-diene-3 $\beta$-ol.

The molecular formula of Philinopgenin $\mathrm{B}$ (2) was determined as $\mathrm{C}_{30} \mathrm{H}_{46} \mathrm{O}_{4}(\mathrm{~m} / \mathrm{z}$ 470) by pseudomolecular ion peaks at $\mathrm{m} / \mathrm{z} 471\left([\mathrm{M}+\mathrm{H}]^{+}\right)$and $493\left([\mathrm{M}+\mathrm{Na}]^{+}\right)$in the HRESI-MS (positiveion mode). The IR spectrum showed absorptions due to hydroxyl $\left(3446 \mathrm{~cm}^{-1}\right)$ and $\gamma$-lactone $\left(1770 \mathrm{~cm}^{-1}\right)$ groups. The ${ }^{13} \mathrm{C}-\mathrm{NMR}$ and DEPT spectrum exhibited 30 carbon signals $\left(7 \times \mathrm{CH}_{3}, 9 \times \mathrm{CH}_{2}\right.$, 
$6 \times \mathrm{CH}, 8 \times \mathrm{C}$ ). The ${ }^{1} \mathrm{H}$ - and ${ }^{13} \mathrm{C}-\mathrm{NMR}$ spectra of compound 2 (Table 1) showed some similarities to those of compound 1 and to those of the aglycone moieties of cucumarioside $G_{2}$ [3]. The main difference from compound 1 being the replacement of the 16 OAc-substitutuent $\left(\delta_{\mathrm{C}} 75.0, \delta_{\mathrm{H}} 5.63\right)$ by one oxygen-bearing methine group $\left(\delta_{\mathrm{C}} 79.2, \delta_{\mathrm{H}} 4.77\right)$ forming the $18(16)$-lactone with the C-18 carbonyl group, in agreement with the chemical shifts for $\mathrm{C}_{15}$ and $\mathrm{C}_{17}$, and the replacement of the side chain by a 2,2-dimethyl-6-pyranyl moiety. The quaternary carbons at $\delta_{\mathrm{C}} 73.0$ and 71.8 suggested that the side chain is in a pyran form. The correct assignments for the side chain are based the fact that the carbon peaks at $\delta_{\mathrm{C}} 73.0(\mathrm{C}-20)$ and $28.2(\mathrm{C}-22) \mathrm{ppm}$ correlate with the methyl protons $\mathrm{H}-21$ and the carbon peaks at $\delta_{\mathrm{C}} 71.8(\mathrm{C}-25)$ and $36.5(\mathrm{C}-24)$ ppm correlate with the methyl protons H-26 and H-27 in the HMBC spectrum. Furthermore, the HMQC spectrum of compound 2 shows that H-22, H-23 and H-24 correlate with the carbon peaks at $\delta_{\mathrm{C}} 33.8 \mathrm{ppm}, 36.5$ and 71.8 ppm respectively. The chemical shifts of the H-22 signals $(\delta 1.48)$ and H-24 signals $(\delta 1.36$, 1.51) showed coupling to signals at $\delta 1.58$ and $1.76(\mathrm{H}-23)$ in the DQCOSY spectrum. This conclusion was also confirmed in the NOESY spectrum (see Figure 1b). Thus, compound 2 was determined as 20,25-epoxylanosta-8(9)-ene-3 $\beta$-ol 18(16)-lactone.

Figure 1: Key NOESY connections in compounds 1 (a), 2 (b) and 3 (c)

(a)

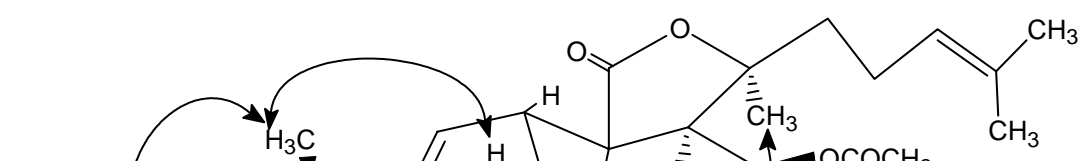

(b)

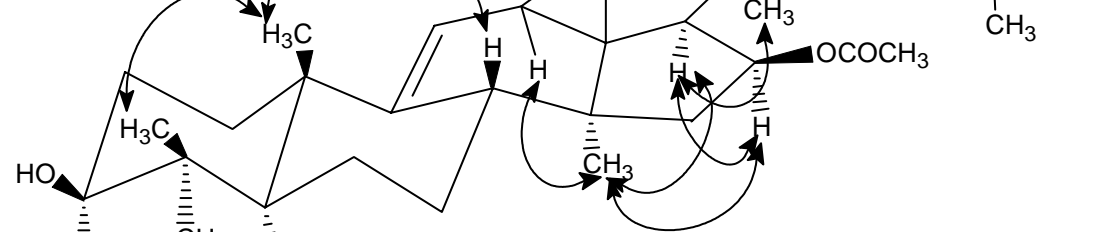

(c)
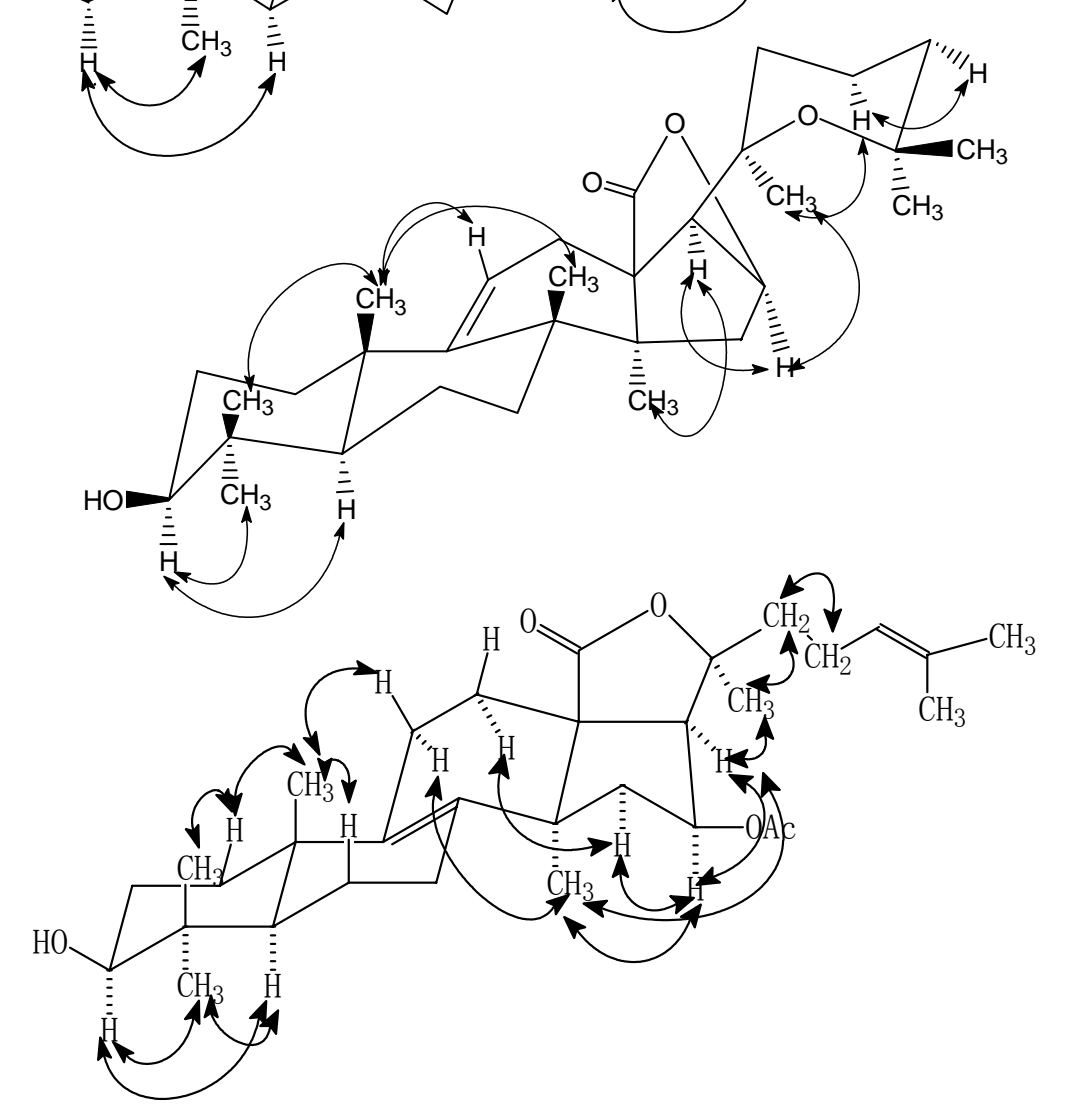
The molecular formula of Philinopgenin $\mathrm{C}$ (3) was determined as $\mathrm{C}_{32} \mathrm{H}_{48} \mathrm{O}_{5}(\mathrm{~m} / \mathrm{z} 512)$ by pseudomolecular ion peaks at $\mathrm{m} / \mathrm{z} 535\left([\mathrm{M}+\mathrm{Na}]^{+}\right)$in the HRESI-MS (positive-ion mode). Compound 3 shows spectral features (Table 1) similar to those of compound 1, except for the signals due to the carbon atoms at the $\mathrm{B} / \mathrm{C}$-ring junction. These findings suggest that compound $\mathbf{3}$ is an olefinic function regioisomer of compound 1. The two olefinic carbon signals at $\delta=130.2$ (s) and 135.6 (s) in the ${ }^{13} \mathrm{C}$-NMR spectrum of compound $\mathbf{3}$ indicate that compound $\mathbf{3}$ is the $\Delta^{8(9)}$ isomer of $\mathbf{1}$.

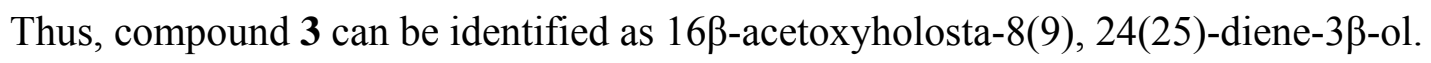

About 40 genuine and artifact triterpenoid aglycones have been obtained by acidic or enzymatic hydrolysis of crude sea cucumber glycosides [4]. The newly obtained aglycones, described in this paper, differ from previously reported ones in their substitution patterns. It should be noted, however, that compounds $\mathbf{1}, \mathbf{2}$, and $\mathbf{3}$ may be artifacts arising from the extraction treatment, because the coexistence of minute amounts of other not identified regioisomers was noted in the acid hydrolysate of the glycoside mixture, and signals due to a trisubstituted olefin group $\left(\Delta^{7(8)}\right)$ were observed in the NMR spectra of the parent oligoglycoside sulfates of this sea cucumber.

\section{Acknowledgments}

This work was supported by the State Foundation for High-Projects Grant "863" from the Ministry of Science and Technology, P. R. China awarded to Y-H Yi.

\section{Experimental}

\section{General}

Melting points were determined with a XT5-XMT micro melting point apparatus and are uncorrected. IR spectrum was measured on a BRUKER VECTOR-22 spectrophotometer. The ESIMS (positive and negative ion modes) was obtained on Micromass Quattro mass spectrometer. ${ }^{1} \mathrm{H}$ $\mathrm{NMR}$ and ${ }^{13} \mathrm{C}$-NMR spectra were recorded in $\mathrm{CDCl}_{3}$ (at $100 \mathrm{MHz}$ and $400 \mathrm{MHz}$ for ${ }^{13} \mathrm{C}$ - and ${ }^{1} \mathrm{H}$ NMR, respectively) with an Inova-400 spectrometer. Chemical shifts are given in $\delta$ values with tetramethylsilane (TMS) as internal standard in ${ }^{1}$ H-NMR. Silica gel (Yantai, 200-300 mesh) was used for column chromatography. Pre-coated silica gel plates (Yantai, HSG, 0.15-0.20mm) were used for analytical TLC. HPLC was carried out with Zorbax 300 SB-C18 reverse phase.columns $(9.4 \times 250 \mathrm{~mm}$, Zorbax).

\section{Animal material}

Specimens of $P$. quadrangnlaris were collected at different locations around the South China Sea (near Guangdong Province, China) and identified by Prof. J. R. Fang of Fujian Institute of Oceanic Research, China in May 2002. A voucher specimen (No. SA200042) is deposited at the Research Center for Marine Drugs, School of Pharmacy, Second Military Medical University, China. 


\section{Extraction and Purification}

Air-dried body walls of the sea cucumber Pentacta quadrangulasis $(10 \mathrm{~kg})$ were extracted with $50 \% \mathrm{EtOH}(50 \mathrm{~L})$. The EtOH was evaporated in vacuo to give a crude extract $(23.1 \mathrm{~g})$, which was partitioned between water $(15 \mathrm{~L})$ and chloroform $(15 \mathrm{~L})$. The water layer was extracted with $\mathrm{n}$ butanol $(15 \mathrm{~L})$ and the organic layer was evaporated in vacuo to give the n-butanol extract $(16.3 \mathrm{~g})$. A portion of this extract $(6.0 \mathrm{~g})$ was heated at reflux in aqueous $15 \% \mathrm{H}_{2} \mathrm{SO}_{4}(2000 \mathrm{~mL})$ and the cooled reaction mixture was then extracted with three portions of chloroform $(800 \mathrm{~mL}, 600 \mathrm{~mL}$ and $600 \mathrm{~mL})$, the combined chloroform extracts were washed with water $(300 \mathrm{~mL})$, dried over $\mathrm{Na}_{2} \mathrm{SO}_{4}$ and concentrated to give an aglycone mixture $(1.890 \mathrm{~g})$. This mixture was separated by flash chromatography on silica gel $(3 \times 40 \mathrm{~cm}$ column, eluent: 4:1 n-hexane/EtOAc, flow rate: $1.5 \mathrm{~mL} / \mathrm{min})$ with detection of eluates by TLC ( $\mathrm{SiO}_{2}, 2: 1 \mathrm{n}$-hexane/EtOAc; SCRC reagent) to yield a main fraction $\left(600.9 \mathrm{mg}, \mathrm{v}_{\mathrm{R}}: 80 \mathrm{~mL}-160 \mathrm{~mL}\right)$. This fraction was further separated by HPLC $(85 \%$ $\mathrm{MeOH} / \mathrm{H}_{2} \mathrm{O}$, flow rate $1.5 \mathrm{~mL} / \mathrm{min}$ ) to afford Philinopgenin A (1) (54.4 mg, $\left.\mathrm{t}_{\mathrm{R}}: 15.91 \mathrm{~min}\right)$, Philinopgenin B (2) (63 mg, $\mathrm{t}_{\mathrm{R}}$ : 16.86 min) and Philinopgenin C (3) (77.7 tR: 17.50min).

\section{Spectral Data}

Philinopgenin A (1): a white powder, $\mathrm{mp} 208.5-208.5^{\circ} \mathrm{C}$; IR $(\mathrm{KBr}): v=3443,2970,2937,2869$, 1770, 1748, 1378, $1240 \mathrm{~cm}^{-1}$; EIMS: $\mathrm{m} / \mathrm{z}=512[\mathrm{M}]^{+}, 493\left[\mathrm{M}-\mathrm{H}_{2} \mathrm{O}, \mathrm{A}\right], 479\left[\mathrm{~A}-\mathrm{CH}_{3}, \mathrm{~B}\right], 435,69$ $\left[\mathrm{C}_{5} \mathrm{H}_{9}\right.$, base peak $] ;{ }^{13} \mathrm{C}-\mathrm{NMR}$ and ${ }^{1} \mathrm{H}-\mathrm{NMR}$ : see Table 1.

Philinopgenin B (2): a white powder, $\mathrm{mp} 212.5-213.5^{\circ} \mathrm{C}$; IR $(\mathrm{KBr}): v=3446,2968,2934,2869$, 1770, $1649 \mathrm{~cm}^{-1}$; EIMS: $\mathrm{m} / \mathrm{z}=470\left[\mathrm{M}^{+}\right], 452\left[\mathrm{~m}^{+}-\mathrm{H}_{2} \mathrm{O}\right], 391,109,69\left[\mathrm{C}_{5} \mathrm{H}_{9}\right.$, base peak]; ${ }^{13} \mathrm{C}-\mathrm{NMR}$ and ${ }^{1} \mathrm{H}$ - NMR: see Table 1.

Philinopgenin $C$ (3): a white powder, $\operatorname{mp} 216.5-217.5^{\circ} \mathrm{C}$; IR $(\mathrm{KBr}): v=3466,2968,2935,1869$, 1770, 1748, 1649, $1030 \mathrm{~cm}^{-1}$; EIMS: m/z = 513 [M+1], 494 [M+1- $\left.\mathrm{H}_{2} \mathrm{O}, \mathrm{A}\right], 479$ [A-CH $\left.3, \mathrm{~B}\right], 435$, $69\left[\mathrm{C}_{5} \mathrm{H}_{9}\right.$, base peak $] .{ }^{13} \mathrm{C}-\mathrm{NMR}$ and ${ }^{1} \mathrm{H}-\mathrm{NMR}$ : see Table 1.

Table $1 .{ }^{13} \mathrm{C}$ - and ${ }^{1} \mathrm{H}$ NMR data for compounds $\mathbf{1}, \mathbf{2}$, and 3

\begin{tabular}{|c|c|c|c|c|c|c|}
\hline Compound & & 1 & & 2 & & 3 \\
\hline Position & $\delta_{\mathrm{C}} \mathrm{mult}^{\mathrm{a}}$ & $\begin{array}{l}\delta_{\mathrm{H}} \text { mult }^{\mathrm{b}} \\
(\mathrm{J} \text { in } \mathrm{Hz})\end{array}$ & $\delta_{\mathrm{C}} \mathrm{mult}^{\mathrm{a}}$ & $\begin{array}{l}\delta_{\mathrm{H}} \text { mult }^{\mathrm{b}} \\
(\mathrm{J} \text { in } \mathrm{Hz})\end{array}$ & $\delta_{\mathrm{C}}$ mult $^{\mathrm{a}}$ & $\begin{array}{l}\delta_{\mathrm{H}} \text { mult }^{\mathrm{b}} \\
(\mathrm{J} \text { in } \mathrm{Hz})\end{array}$ \\
\hline 1 & $36.6 \mathrm{t}$ & $\begin{array}{c}\mathrm{H}_{\alpha} 1.44 \mathrm{~m} \\
\mathrm{H}_{\beta} 1.80\end{array}$ & $35.9 \mathrm{t}$ & $\begin{array}{l}\mathrm{H}_{\alpha} 1.43 \mathrm{~m} \\
\mathrm{H}_{\beta} 1.87 \mathrm{~m}\end{array}$ & $36.0 \mathrm{t}$ & $\begin{array}{l}\mathrm{H}_{\alpha} 1.45 \mathrm{~m} \\
\mathrm{H}_{\beta} 1.84 \mathrm{~m}\end{array}$ \\
\hline 2 & $28.0 \mathrm{t}$ & $\begin{array}{l}\mathrm{H}_{\alpha} \\
\mathrm{H}_{\beta}\end{array}$ & $27.8 \mathrm{t}$ & $\begin{array}{l}\mathrm{H}_{\alpha} 1.68 \mathrm{~m} \\
\mathrm{H}_{\beta} 1.72 \mathrm{~m}\end{array}$ & $27.8 \mathrm{t}$ & $\begin{array}{l}\mathrm{H}_{\alpha} \\
\mathrm{H}_{\beta}\end{array}$ \\
\hline 3 & $79.1 \mathrm{~d}$ & $\begin{array}{c}3.34, \mathrm{dd}(5.2 \\
11.6)\end{array}$ & $78.3 d$ & $\begin{array}{c}3.20 \mathrm{dd},(4.6 \\
11.6)\end{array}$ & $79.0 \mathrm{~d}$ & $\begin{array}{c}3.21 \mathrm{dd},(5.2 \\
11.6)\end{array}$ \\
\hline 4 & $40.0 \mathrm{~s}$ & & $39.2 \mathrm{~s}$ & & $38.5 \mathrm{~s}$ & \\
\hline
\end{tabular}


Table 1. Cont.

\begin{tabular}{|c|c|c|c|c|c|c|}
\hline \multirow{2}{*}{$\begin{array}{c}\text { Compound } \\
\text { Position }\end{array}$} & \multicolumn{2}{|r|}{1} & \multicolumn{2}{|r|}{2} & \multicolumn{2}{|r|}{3} \\
\hline & $\delta_{\mathrm{C}} \mathrm{mult}^{\mathrm{a}}$ & $\begin{array}{l}\delta_{\mathrm{H}} \text { mult }^{\mathrm{b}} \\
(\mathrm{J} \text { in } \mathrm{Hz})\end{array}$ & $\delta_{\mathrm{C}} \mathrm{mult}^{\mathrm{a}}$ & $\begin{array}{l}\delta_{\mathrm{H}} \text { mult }^{\mathrm{b}} \\
(\mathrm{J} \text { in Hz})\end{array}$ & $\delta_{\mathrm{C}} \mathrm{mult}^{\mathrm{a}}$ & $\begin{array}{l}\delta_{\mathrm{H}} \mathrm{mult}^{\mathrm{b}} \\
(\mathrm{J} \text { in Hz})\end{array}$ \\
\hline 5 & $52.6 \mathrm{~d}$ & $0.90, \mathrm{~d}, 11.0$ & $52.6 \mathrm{~d}$ & $0.86 \mathrm{tr}$ & $52.5 \mathrm{~d}$ & $0.90 \mathrm{~m}$ \\
\hline 6 & $21.4 \mathrm{t}$ & $\begin{array}{l}\mathrm{H}_{\alpha} 1.58 \mathrm{~m} \\
\mathrm{H}_{\beta} 1.75 \mathrm{~m}\end{array}$ & $21.1 \mathrm{t}$ & $\begin{array}{l}\mathrm{H}_{\alpha} 1.46 \mathrm{~m} \\
\mathrm{H}_{\beta} 1.70 \mathrm{~m}\end{array}$ & $21.0 \mathrm{t}$ & $\begin{array}{l}\mathrm{H}_{\alpha} 2.07 \mathrm{~m} \\
\mathrm{H}_{\beta} 2.07 \mathrm{~m}\end{array}$ \\
\hline 7 & $28.0 \mathrm{t}$ & $\begin{array}{l}\mathrm{H}_{\alpha} \\
\mathrm{H}_{\beta}\end{array}$ & $28.3 \mathrm{t}$ & $\begin{array}{l}\mathrm{H}_{\alpha} 1.78 \mathrm{~m} \\
\mathrm{H}_{\beta} 1.78 \mathrm{~m}\end{array}$ & $27.8 \mathrm{t}$ & $\begin{array}{l}\mathrm{H}_{\alpha} 1.36 \mathrm{~m} \\
\mathrm{H}_{\beta} 1.62 \mathrm{~m}\end{array}$ \\
\hline 8 & $39.6 \mathrm{~d}$ & $\begin{array}{c}3.22, \mathrm{dd}(2.4 \\
13.2)\end{array}$ & $43.4 d$ & & $130.2 \mathrm{~s}$ & \\
\hline 9 & $151.2 \mathrm{~s}$ & & $151.3 \mathrm{~s}$ & & $135.6 \mathrm{~s}$ & \\
\hline 10 & $40.5 \mathrm{~s}$ & & $39.4 \mathrm{~s}$ & & $39.3 \mathrm{~s}$ & \\
\hline 11 & $110.8 \mathrm{~d}$ & $5.16 \mathrm{~s}$ & $113.4 \mathrm{~d}$ & $5.40 \mathrm{~d},(6.0)$ & $27.8 \mathrm{t}$ & \\
\hline 12 & $34.0 \mathrm{t}$ & $\begin{array}{l}\mathrm{H}_{\alpha} 2.36 \mathrm{~m} \\
\mathrm{H}_{\beta} 2.36 \mathrm{~m}\end{array}$ & $24.9 \mathrm{t}$ & $\begin{array}{l}\mathrm{H}_{\alpha} 2.33 \mathrm{~m} \\
\mathrm{H}_{\beta} 2.40 \mathrm{~m}\end{array}$ & $32.3 \mathrm{t}$ & $\begin{array}{l}\mathrm{H}_{\alpha} 2.40 \mathrm{~m} \\
\mathrm{H}_{\beta} 2.45 \mathrm{~m}\end{array}$ \\
\hline 13 & $58.6 \mathrm{~s}$ & & $54.8 \mathrm{~s}$ & & $59.6 \mathrm{~s}$ & \\
\hline 14 & $43.2 \mathrm{~s}$ & & $40.4 \mathrm{~s}$ & & $44.7 \mathrm{~s}$ & \\
\hline 15 & $44.1 \mathrm{t}$ & $\begin{array}{l}\mathrm{H}_{\alpha} 2.19 \mathrm{~m} \\
\mathrm{H}_{\beta} 1.43 \mathrm{~m}\end{array}$ & $42.0 \mathrm{t}$ & $\begin{array}{l}\mathrm{H}_{\alpha} 1.56 \mathrm{~m} \\
\mathrm{H}_{\beta} 1.74 \mathrm{~m}\end{array}$ & $41.1 \mathrm{t}$ & $\begin{array}{l}\mathrm{H}_{\alpha} 2.22 \mathrm{~m} \\
\mathrm{H}_{\beta} 1.42 \mathrm{~m}\end{array}$ \\
\hline 16 & $75.0 \mathrm{~d}$ & $5.76 \mathrm{~m}$ & $79.2 \mathrm{~d}$ & $4.77 \mathrm{tr}$ & $75.0 \mathrm{~d}$ & $5.63 \mathrm{~m}$ \\
\hline 17 & $52.9 \mathrm{~d}$ & $2.57 \mathrm{~d}(9.6)$ & $63.5 \mathrm{~d}$ & $2.25 \mathrm{~m}$ & $52.3 \mathrm{~d}$ & $2.51 \mathrm{~d},(9.6)$ \\
\hline 18 & $176.7 \mathrm{~s}$ & & $178.1 \mathrm{~s}$ & & $176.8 \mathrm{~s}$ & \\
\hline 19 & $22.3 q$ & $1.30 \mathrm{~s}$ & $21.5 \mathrm{q}$ & $1.25 \mathrm{~s}$ & $21.8 \mathrm{q}$ & $1.19 \mathrm{~s}$ \\
\hline 20 & $84.8 \mathrm{~s}$ & & $73.0 \mathrm{~s}$ & & $84.4 \mathrm{~s}$ & \\
\hline 21 & $28.8 \mathrm{q}$ & $1.36 \mathrm{~s}$ & $26.0 \mathrm{~s}$ & $1.25 \mathrm{~s}$ & $28.2 q$ & $1.50 \mathrm{~s}$ \\
\hline 22 & $38.5 \mathrm{t}$ & $\begin{array}{l}\mathrm{H}_{\alpha} 1.96 \mathrm{~m} \\
\mathrm{H}_{\beta} 2.30 \mathrm{~m}\end{array}$ & $33.8 \mathrm{t}$ & $\begin{array}{l}\mathrm{H}_{\alpha} 1.48 \mathrm{~m} \\
\mathrm{H}_{\beta} 1.48 \mathrm{~m}\end{array}$ & $38.4 \mathrm{t}$ & $\begin{array}{l}\mathrm{H}_{\alpha} 1.76 \mathrm{~m} \\
\mathrm{H}_{\beta} 2.42 \mathrm{~m}\end{array}$ \\
\hline 23 & $23.8 \mathrm{t}$ & $\begin{array}{l}\mathrm{H}_{\alpha} 1.98 \mathrm{~m} \\
\mathrm{H}_{\beta} 2.02 \mathrm{~m}\end{array}$ & $16.3 \mathrm{t}$ & $\begin{array}{l}\mathrm{H}_{\alpha} 1.58 \mathrm{~m} \\
\mathrm{H}_{\beta} 1.76 \mathrm{~m}\end{array}$ & $23.5 \mathrm{t}$ & $\begin{array}{l}\mathrm{H}_{\alpha} 1.92 \mathrm{~m} \\
\mathrm{H}_{\beta} 2.11 \mathrm{~m}\end{array}$ \\
\hline 24 & $124.4 \mathrm{~d}$ & $5.04 \mathrm{~d}(11.2)$ & $36.5 \mathrm{t}$ & $\left.\mathrm{H}_{\alpha} 1.36 \mathrm{~m}\right)$ & $123.7 \mathrm{~d}$ & $5.05 \mathrm{~d},(11.2)$ \\
\hline 25 & $131.8 \mathrm{~s}$ & & $71.8 \mathrm{~s}$ & & $132.1 \mathrm{~s}$ & \\
\hline 26 & $25.5 q$ & $1.57 \mathrm{~s}$ & $32.7 q$ & $1.13 \mathrm{~s}$ & $25.5 q$ & $1.69 \mathrm{~s}$ \\
\hline 27 & $17.7 \mathrm{q}$ & $1.50 \mathrm{~s}$ & $28.4 q$ & $1.20 \mathrm{~s}$ & $18.6 q$ & $1.60 \mathrm{~s}$ \\
\hline 30 & $16.4 q$ & $0.98 \mathrm{~s}$ & $15.2 q$ & $0.80 \mathrm{~s}$ & $15.4 q$ & $0.85 \mathrm{~s}$ \\
\hline 31 & $28.6 q$ & $1.10 \mathrm{~s}$ & $28.3 q$ & $0.98 \mathrm{~s}$ & $28.1 \mathrm{q}$ & $1.02 \mathrm{~s}$ \\
\hline 32 & $21.4 q$ & $0.80 \mathrm{~s}$ & $21.7 \mathrm{q}$ & $1.07 \mathrm{~s}$ & $27.0 \mathrm{q}$ & $1.10 \mathrm{~s}$ \\
\hline $\mathrm{CH}_{3} \underline{\mathrm{COO}}$ & $170.0 \mathrm{~s}$ & & & & $170.3 \mathrm{~s}$ & \\
\hline$\underline{\mathrm{CH}_{3} \mathrm{COO}}$ & $21.4 \mathrm{q}$ & $1.93 \mathrm{~s}$ & & & $21.0 \mathrm{q}$ & $2.02 \mathrm{~s}$ \\
\hline
\end{tabular}


${ }^{a}$ Recorded at $100 \mathrm{MHz}$ in $\mathrm{CDCl}_{3}$; multiplicity by DEPT.

${ }^{\mathrm{b}}$ Recorded at $400 \mathrm{MHz}$ in $\mathrm{CDCl}_{3}$

\section{References}

1. Katagawa, T.; Sugawara, I.; Yosioka, K. Saponin and Sapogenol. XIV. Antifungal Glycosides from the Sea Cucumber Stichopus japonicus Selenka. Chem. Pharm. Bull. 1976, 24, 266-274

2. Girard, M.; Bélanger, J.; ApSimon, J.W.; Garneau, F-X.; Harvey, C.; Brisson, J-R. Frondoside A. A novel triterpene glycoside from the holothurian Cucumaria frondosa. Can. J. Chem. 1990, $68,11-18$

3. Avilov, S.A.; Antonov, A.S.; Drozdova. O.A. Kalinin, V.I.; Kalinovsky, A.I.; Stonik, V.A.; Riguera, R.; Lenis, L.A.; Jiménez. C. Triterpene Glycosides from the Far-East Sea Cucumber Pentamera calcigera. 1. Monosulfated Glycosides and Cytotoxicity of Their Unsulfated. J. Nat. Prod. 2000, 65-71

4. Burnell, DJ. Apsimon, JW. In Marine Natural Products - Chemical and Biochemical Perspectives; Scheuer, P.J., Ed; Academic Press: New York; 1983; Vol. 5, pp. 287-389

Sample Availability: Samples are available from the authors.

(C) 2004 by MDPI (http://www.mdpi.org). Reproduction is permitted for noncommercial purposes. 